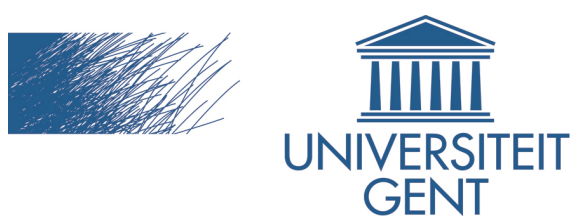

biblio.ugent.be

The UGent Institutional Repository is the electronic archiving and dissemination platform for all UGent research publications. Ghent University has implemented a mandate stipulating that all academic publications of UGent researchers should be deposited and archived in this repository. Except for items where current copyright restrictions apply, these papers are available in Open Access.

This item is the archived peer-reviewed author-version of: ID 4307234

Title Historical Reflections on Progress and Tradition

Authors R.C. van Caenegem

In: Journal, Volume (Issue), pages, year.

European Review / Volume 22 / Issue 01 / February 2014, pp 170 - 178

Published online: 26 February 2014

Optional: link to the article

Link to this article: http://journals.cambridge.org/abstract_S1062798713000719

To refer to or to cite this work, please use the citation to the published version:

Authors (year). Title. journal Volume(Issue) page-page. Doi

DOI: $10.1017 /$ S1062798713000719 


\section{Historical reflections on progress and tradition.}

\section{R.C. van Caenegem}

At the time of writing I was watching the conflict in Egypt between the progressive, liberal movement and the sympathizers with the Muslim Brotherhood, who defended ancient traditions. I began to wonder whether Europe, in its long history, passed through similar convulsions, in a pattern which teaches us something.

\section{The nineteenth century}

The age of Queen Victoria immediately came to my mind because in her country public life was marked by the clash between progressives and traditionalists. The liberals and the conservatives even gave their names to the two dominating parties, which produced the best known Prime Ministers, Gladstone of the Liberal and Disraeli of the Conservative Party. The liberals stood for modernization and were critical of the monarchy and of religion, whereas their rivals were defenders of ancient traditions and closer to the throne and the Church. The supporters of the "good old times" managed, for example, to block attempts to reform the medieval House of Lords ${ }^{i}$. It was typical of this deep seated ideological conflict that, when the two precursors of the University of London were founded, University College and King's College, the former, 
created in 1828, was to be a freethinking bastion, whereas the latter was an Anglican response given by traditional forces.

Nineteenth-century Belgium was similarly divided between progressive, anticlerical liberals and traditional ultramontane Catholics. Their two parties, called the Liberal and the Catholic, ruled the country and fought each other vigorously. Their ideological battle came to a head with the so-called School War (1879-1884), when the Liberal government promoted "neutral" state schools in order to undermine traditional Catholic education. The confrontation was so bitter that teachers who accepted work in the "godless" schools were excommunicated.

Just as happened in London and at the same time, the two ideologies founded their own universities to defend their principles, the Universite Catholique de Louvain (linked to the medieval university abolished at the French Revolution) and the Université Libre de Bruxelles.

The Belgian Revolution of 1830 was successful because of a temporary coalition of liberals and Catholics who were as one against King William of the United Netherlands ii. The liberals wished to topple him because he was too autocratic, and the Catholics found him too Enlightened and Protestant. However, as soon as the monarch was gone the two groups fell out. There is a striking similarity with events in present-day Egypt, where the Muslim Brotherhood and the liberals have been united against President Mubarak but started quarrelling as soon as he had left ${ }^{\mathrm{iii}}$.

Several other countries were confronted with the same conflict, and there is no need to expatiate on it. It is, however, apposite to point out the moral support offered by the papacy to conservative interests in Catholic countries. Pope Pius IX roundly condemned such modern "errors" as popular sovereignty, constitutions and parliaments, human rights, equality, freedom of thought, of 
conscience and of religion. The full catalogue of these "errors" was published as an annex to the encyclical Quanta cura of 1864, known as the Syllabus errorum (the list of errors) ${ }^{\text {iv }}$.

\section{The eighteenth century}

In France the age of Voltaire and Diderot saw a clear divide between the traditionalist supporters of kingship and Church and the progressive believers in the Enlightenment of Diderot and d'Alembert's Encyclopédie.

The conservatives stood by absolute monarchy, the intellectual superiority of the Eglise gallicane and the privileges of the nobility (in 1789 all French bishops were noblemen). Their opponents believed in democracy and equality and followed human reason instead of religious dogma.

The Etats Généraux, the French parliament, meeting in 1789 for the first time since 1614, gave the progressives their chance. They called themselves the National Assembly and introduced, following the English model, constitutional monarchy and government controlled by an elected assembly. The Assembly published the Déclaration des Droits de l'Homme et du Citoyen and abolished feudalism, serfdom and class privilege. The French Church was nationalized and its landed wealth expropriated. The clergy was integrated into the State by the Constitution civile du clergé of 1790 and regarded as a public service. This straightforward tale of a progressive victory was typical of France, but not of Europe.

In England, for example, following the Glorious Revolution of 1689, absolute kingship was no longer argued about, nor, following the Toleration Act of 1689 and the abolition of censorship in 1695, was religious persecution a topic. 
In central Europe the situation was more complicated, as Enlightened rulers such as Frederik II of Prussia (a friend of Voltaire) and Joseph II of Austria pursued progressive politics for the wellbeing of their subjects. They issued modern codes of private law, humanized criminal law and abolished torture. Frederik favoured religious freedom, saying that "in his kingdom everyone could be saved in his own way".

Joseph II abolished "useless" contemplative orders, introduced compulsory schooling and issued a Patent of Toleration in favour of faiths other than the Catholic. He moreover, introduced civil marriage and divorce. Those emperors and kings did not, however, extend modernisation to the political sphere: they stuck to the tradition of personal rule, without constitutional curbs or parliamentary control. This mix of progress and tradition was rather strange, but even stranger were the events in France after the coup d'état of 1792.

The first phase of the Revolution was moderate: the monarchy was saved, the Catholic faith respected and, as revolutions go, there had been little bloodshed. Things changed in August 1792, when the Revolution took a radical turn and the Convention Nationale, dominated by extremists, assumed full power. The monarchy was abolished, the republic proclaimed, the king and the queen executed and Christianity outlawed and replaced by the cult of the goddess Reason. A regime of terror was installed and political opponents and class enemies guillotined or otherwise put to death en masse. The Convention was the sole instrument of the State, parliament and government combined, and there was no President of the republic or head of State.

Does this phase fit in my paradigm of progress versus tradition? If progress means democracy, liberty and the rule of law those fateful years obviously do not qualify. Nor, clearly was it in favour of tradition, for what the radicals aimed at was the destruction of the most hallowed traditions of the French nation, kingship and Christianity. 
So the question remains what to make of these fateful events. It is clear that a good idea could get out of hand and, when pushed relentlessly to extremes, lead to absurd and selfdefeating consequences. The radicals mercilessly forced their ideas on everyone. As a German poet said sarcastically: "Und willst du nicht mein Bruder sein, so schlag'ich dir den Schädel ein" (if you refuse to be my brother, I will bash your head in).

A similar drama took place after the Russian October Revolution of 1917, when high hopes of a new dawn of freedom were dashed by Stalin's terror.

As the eighteenth century drew to a close, so did the French Revolution, when a general grabbed power and ruled as Premier Consul and then as Empereur des Français.

\section{The seventeenth century}

In the age of Galilei and Newton scientists achieved triumphs, but for democrats and liberals Europe was a dismal place. Absolute kings triumphed ${ }^{\mathrm{v}}$ - Magna Carta fell into oblivion and parliaments were ignored - and religious and other wars were endemic.

In England, however, events did not completely follow this pattern and therefore deserve our special attention. The Stuart kings James I, who wrote learned treatises on kingship by divine right, and Charles I, who ruled without Parliament from 1628 to 1640 , were autocratic monarchs in the continental fashion. For a long time they managed to keep the opposition at bay, both its political, who defended Parliament, and its religious wing, who were Puritans and strict Calvinists. But in 1640 the Scottish war led to the recall of Parliament and the anti-royalists grabbed their chance: the Puritan Revolution broke out and the country was dragged into a civil war between the royalists and their 
opponents. Finally the rebellion won the day, and its leader, Oliver Cromwell, proclaimed the Republic. The monarchy was abolished and King Charles executed in 1649. In 1646 the episcopal hierarchy of the State Church had been abolished (in 1645 Archbishop Laud, a thorn in the Puritan flesh, was executed). How are we to evaluate the short-lived Puritan Republic (the monarchy was restaured in 1660)? Toppling an autocratic king, proclaiming a republic and reviving Parliament were democratic achievements. The Republic professed to believe in Liberty: the new-born State called itself the "Commonwealth or Free State", and on the Great Seal 1649 was called "the first year of freedom by God's blessing restored". The plan of codifying the law and the replacement of Law French ${ }^{\text {vi }}$ by plain English were democratic steps.

The exalted phrases about Freedom did not, however, mean that Cromwell was leading his people to a promised land of liberalism. On the contrary, he proceeded, as a true fundamentalist, to impose his own puritanical, rightenous and God-fearing way of life, including the death penalty for adultery and a ban on the theatre, as being too frivolous. Iconoclastic zealots destroyed or mutilated religious works of art: the stained-glass windows of King's College Chapel in Cambridge avoided being smashed in the nick of time. So the Puritan Revolution managed to bring down autocratic kingship, only to replace it by an intolerant Cromwellian republic. The events in Iran in our own time were very similar: the Ayatollahs overthrew the autocratic regime of the Shah, only to replace it by their own oppressive Islamic Republic.

\section{The sixteenth century}

In the age of Erasmus, Luther and Calvin Europe was divided in a progressive and a traditional camp. The humanists, whose uncrowned king was Desiderius Erasmus, were a liberating force which broke free from the shackles of medieval 
scholasticism and broadened people's outlook. They were at the dawn of a new age and wrote ironically about the credulity and superstition of their forefathers. In the first half of the fifteenth century the Italian humanist Lorenzo Valla demonstrated that the Donatio Constantina was a fake. It pretended to be a diploma in which Emperor Constantine the Great, upon moving the seat of his government from Rome to Constantinople, granted the pope the governance of the Occident, and had been fabricated in the eighth century ${ }^{\text {vii }}$. If it took some naievety to believe in Constantine's grant, a set of spurious documents fabricated in Austria around the middle of the fourteenth century and known as the Privilegium maius, some of which pretended to be grants by Julius Caesar (!) and Emperor Nero (!) was even more farfetched. When the famous humanist Petrarca was consulted about its authenticity, he told the Austrians in 1361 that their precious privileges were the work of a falsifier described as an asellus

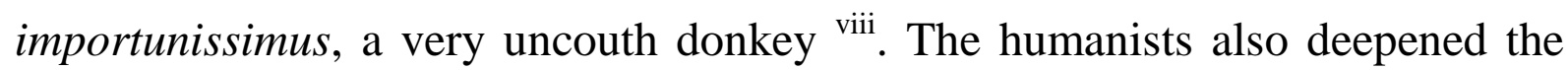
understanding of Antiquity and studied the three languages at the cradle of Western civilisation, Hebrew, Greek and Latin. Their critical ideas inspired such pathbreaking scientists as the astronomer Copernic and the anatomist Vesalius. Ideally the humanists hoped for a tolerant and peaceful European republic of letters.

The Protestants were progressive, as they broke the domimation of the monolithic papal Church. They proclaimed everybody's right to interpret Holy Writ, not constrained by the dictates of the hierarchy: freedom of conscience was encouraged.

The Emperor Charles V was an imposing figure in the conservative camp. He stood for tradition and fought heresy in the criminal courts and on the battlefield. The Fathers of the Council of Trent were on the same wavelength: they were the voice of the Counterreformation and accentuated papal centralism. 
The two views crossed swords for most of the century. Viewing the ideological battlefield at its end, an observer would have found the sad spectacle of dashed hope. The humanists' peaceful and tolerant republic of letters proved a forlorn pipedream in a fanatical age of wars and religious persecution. Luther's idea of reforming the Church from within - the original meaning of the Reformation in fact led to the breakup of the Roman Church the greatest legacy of the Middle Ages. Only parts of Germany, Scandinavia, parts of Poland and parts of Hungary followed the lead of the rebellious Augustinian monk.

Calvin's ambition to reconstruct the whole of Christendom was thwarted, as only Switzerland, Holland and Scotland joined in, while France, after a bloody civil war, remained in the papal camp. The conservatives were equally infortunate. Heresy proved ineradicable and the Roman Church had to live with the reality that large parts of Europe - the Lutheran and Calvinist countries as well as England - escaped papal control (Philip II's ambition to conquer England and Holland for Catholicism failed).

Not to end on a sombre note, I see one point of light: the growing freedom of thought. There now existed religious diversity and, though total freedom was still far away, people could - if they left in time - escape from coercion: Flemish Protestants fled to Queen Elizabeth's England and her own Catholic subjects fled to Flanders to live their faith and study at Leuven or Douai or enter an English convent in Bruges, Ghent or Ypres.

\section{The fifteenth century}

My last case study concerns the constitution of the Church. About A.D. 1400 Latin Christendom witnessed an attempt to make the general council the supreme authority instead of the papal curia - in modern terms to make the pope a constitutional head restricted by parliament. 
The great oecumenical councils of that period brought together clerics and laymen from all over western Christendom, they were the first European parliament. They deliberated, issued new laws and made the papal curia an organ of the Church and not its master. They embodied a progressive move against a centuries-old tradition.

In the fourteenth century scholars like Marsilius of Padua had criticized the autocratic papal system and wanted the oecumenical council to be the sovereign legislator. They hoped for a transition from papal absolutism to a democratic conciliar constitution - a triumph for the ascending theory of power ${ }^{\text {ix }}$. This had been a pipedream for a long time, as defying the Vicar of Christ on earth seemed unrealistic. Yet, quite unexpectedly, the Great Western Schism (1387-1417) gave the lie to the pessimists. For three quarters of a century the popes, under French influence, had resided in Avignon, until under popular demand for the Roman pontiff to return to Rome, the cardinals in 1378 elected an Italian, Urban VI, who decided to move to Rome. But soon afterwards a caucus of French cardinals elected a French pope, Clement VII, who went to live in Avignon. Henceforth, both claiming legitimacy and excommunicating each other. Christianity was divided in two, as one half followed the pope of Rome and the other the pope of Avignon. This conflict at the top gave the conciliar movement a chance to put its ideas into practice and to convene a general council representing the whole of Christendom, to assume control, restore unity and reform the Church in depth. The autocratic papacy would be toppled, not by mass demonstrations but by a self-inflicted crisis at the top.

The council of Pisa met in 1409 and was attended by numerous bishops, abbots, university dons and representatives of rulers and cities. It declared itself competent to solve the schism, deposed the two then popes, Benedict XIII and Gregory XII ${ }^{x}$, as schismatics and heretics, and elected their own pope, Alexander V. But, as the two deposed leaders rejected the legitimacy of the 
council, the Church was governed - or supposed to be - by three popes. The situation was so desperate that another general council was convened to put things right. This was the council of Constance (1414-1418), dominated by the progressive reformist party. It was the largest medieval assembly, attended by hundreds of prelates and princes, as well as some one hundred doctors of theology or law. The council decided to vote by nation and not by head (concilium constituitur ex nationibus), the Germans, Italians, French, English and Spaniards being predominant. They held committee meetings and plenary sessions. On 26 March and 6 April 1415 the council, to which the papal government was to be subordinate, claimed supreme authority. The schism was brought to an end by the election on 11 November 1417 of Pope Martin V (1417-1431) by a body of cardinals and representatives of the leading nations. Constance was an exercise in democracy, turning the papal Church into the people's Church . It was the supreme moment for the conciliar movement, for under Martin V the papal restauration was already under way. The next council, held at Basel (1431-1437/1449) ran into trouble as, in 1437, Pope Eugenius IV, elected in 1431 after Martin V's death, decided to move to Ferrara, but was followed only by a minority, the others continuing in Basel. In 1439 they defined as dogma that the general council was supreme and that denying this amounted to heresy. Basel moreover deposed Pope Eugenius IV as a schismatic and heretic. However, lack of support by the crowned heads weakened the council, which petered out and came to an end in Lausanne in 1449. It had overreached itself: the election in 1439 of duke Amadeus of Savoy, a widower, as Pope Felix V (1439-1449) had been a desperate and even aberrant move, and the conservatives in the Church had not disarmed. At the "papal" council of Ferrara, soon transferred to Florence (1438-1442), the defenders of the age-old tradition gained the upper hand and restaured the papal supremacy. The descending theory of power triumphed, the abhorred decrees of Basel were annulled and their authors condemned as heretics and excommunicated. In 1442 
the council moved to Rome. The restauration had been supported by the book of the Spanish theologian and cardinal Juan de Torquemada, who had strongly condemned conciliarism in Basel and was papal adviser in Ferrara.

The brief interlude of Pisa, Constance and Basel - a mere thirty years - seemed misguided, a deviation or even an aberration from a venerable tradition. The fourteenth-century pipedream had turned into a nightmare for the papacy, and Rome was determined that there would be no repetition. As recently as 1983 the Codex Iuris Canonici stipulated in canon 1372 that whoever appealed to an oecumenical council against an edict of the Roman pontiff should be punished. What is the modern reader to make of all this? He will sympathise with the attempt of the progressives to limit papal absolutism and give power to a broadly based assembly. The reformers, however, found that government by an assembly was impractical and the rulers withdrew their initial support when they came to distrust the democratic surge behind the conciliar movement.

Some influential clerics, who had been active in Basel, went over to the papal side to find stability. Aenea Silvio Piccolomini, for example, had been a moderate conciliarist in Basel, for a while even supporting Felix V, but later turned his back on conciliarism, became a cardinal in 1456 and ended as Pope Pius II (1458-1464). He was one of the most prestigious old-style Church leaders and a humanist who built the Palazzo Piccolomini in Pienza, well known to tourists in Italy.

The reformatio ecclesiae of the fifteenth century was the last major attempt to reform the Church from within, for the sixteenth-century Reformation broke up medieval Christendom ${ }^{\mathrm{xi}}$. 


\section{Conclusion}

Is the chain of events under review meaningful or was it just "one damn thing after another", a "tale told by an idiot, full of sound and fury, signifying nothing"?

From a democratic point of view the European experience was admittedly not encouraging. Progressive endeavours have all too often been less than successful. In some cases the reformers have failed completely to reverse the existing autocratic order: the conciliar movement comes to mind. In other cases the rebellion against one oppressive regime led to another such regime, but inspired by a different ideology: the Puritan Revolution comes to mind.

In yet other instances the initial success of the liberal ideology was pushed to such extremes that State terrorism was the result: the French Revolution comes to mind.

Sometimes partial success was obtained, when progressive policies were pursued by autocratic rulers, attached to their own political tradition: the Enlightened emperors and kings come to mind. 
Fortunately there was sometimes a completely successful outcome, when an autocracy retreated before progressive action: the English Glorious Revolution and resulting constitutional and parliamentarian government come to mind.

To end on an even more optimistic note, it is clear that in the long run and in spite of many pitfalls (such as the twentieth-century dictatorships) progressive democratic and liberal aspirations have won the day: present-day Europe comes to mind.

\author{
R.C. van Caenegem \\ SUMMARY
}

Progress and Tradition

Reflecting on tension between progressives and traditionalists in present-day Egypt, the author surveys comparable conflicts in the European past. In nineteenth-century Britain and Belgium the struggle between liberals and conservatives dominated public life. In eighteenth-century France the progressive forces of the Enlightenment were for a long time in bitter conflict with the traditional defenders of King and Church, until the latter were defeated at the French Revolution. In seventeenth-century England the Puritan Revolution overthrew Stuart absolutism, which was a democratic move, but Cromwell then established his own fundamentalist Republic, which was illiberal. In the sixteenth century Humanists and Protestants were progressive and broke with medieval modes of thought and papal domination, but were opposed by traditional forces around the House of Habsburg and the Counterreformation, neither party claiming total victory. By the fifteenth the 


\section{progressive conciliar movement attempted to democratize the Catholic Church}

by putting the papal curia under the supreme authority of the general council, an assembly representing Christian people of all nations. This short-lived attempt was foiled by defenders of the traditional papal supremacy.

\footnotetext{
${ }^{\mathrm{i}}$ P. RAINA, House of Lords Reform: A History. Book One, The Origins to 1911, Oxford, Peter Lang, 2011.

ii This kingdom was an amalgam of the Austrian Netherlands and the Dutch Republic, created by the Congress of Vienna in 1815, and harking back to the sixteenth-century Habsburg Netherlands. King William was a descendant of William the Silent and the stadtholders of Holland.

${ }^{\text {iii }}$ See the brilliant analysis in B.K. RUTHERFORD, Egypt after Mubarak. Liberalism, Islam, and Democracy in the Arab World, Princeton University Press, 2013.

iv The full title was Syllabus complectens praecipuos nostrae aetatis errores, i.e. A catalogue containing the main errors of our time.

"The Latin solutus or absolutus means "free from, not bound by", so absolute kings were above the law. The notion goes back to the Roman law phrase Princeps legibus solutus est, the emperor is not bound by the laws. ${ }^{v i}$ Law French was the technical language of the "common-law courts, going back to the Newman occupation, and completely ununderstandable to ordinary people.

vii W. Setz, Lorenzo Vallas Schrift gegen die Konstantinische Sehensung, Tübingen, 1975.

viii A. LHOTSKY, Privilegium maius. Die Geschichte einer Urkunde, Munich and Vienna, 1957.

${ }^{i x}$ In the ascending theory of government original power is anchored in the people, in the descending thesis original power is located in a supreme being: God distributing the laws to mankind through the medium of kings (W. ULLMANN, A History of Political Thought: the Middle Ages, Harmondsworth, 1965, pp. 12-13.

${ }^{x}$ Gregory XII succeeded Innocent VII in 1406 in Rome. At the council of Constance he resigned in 1415 and died in 1417.

${ }^{\mathrm{xi}}$ The bibliography on the subject is extensive. The reader can consult the classic study by B. TIERNEY, Foundations of the Conciliar Theory, Cambridge Univ. Press 1968. See also a recent work by M. DECALUWE, $A$ successful defeat. The papal politics of pope Eugene IV towards the council of Basel, Brussels, Rome, 2009 (Bibliotheek van het Belgisch Historisch Instituut te Rome, LIX).
} 